Int. Archs Allergy appl. Immun. 1983;70:I-IV

\title{
Contents, Vol. 70, 1983
}

\section{Vol. 70, 1983}

International Archives

of Allergy and Applied

Immunology

Founded 1950 by D. Harley, P. Kallós, W. Löf Пer and F.W. Wittich Continued by E.A. Brown (1952-1954), W. Kaufman (1955-1967). F. Hahn (1961-1972) and H.C. Goodman (1963-1975)

Editors-in-Chief

R.R.A. Coombs, Cambridge L.Ä. Hanson, Göteborg P. Kallós, Helsingborg F. Milgrom, Buffalo, N.Y. Z. Trnka, Basel G.B. West, Epsom

Liaison Editors

J.M. Cruse, Jackson, Miss. L.M. Schwartz, East Orange, N.J.

Contributing Editors

C.J. Abeyounis, Buffalo, N.Y.

N.F. Adkinson, Jr., Baltimore, Md.

B. Albini, Buffalo, N.Y.

G. Andres, Buffalo, N.Y.

E.L. Becker, Farmington, Conn.

L. Belin, Göteborg

W.E. Brocklehurst, Windlesham

A. Cerletti, Basel

C.G. Cochrane, La Jolla, Calif.

B. Diamant. Copenhagen

P. Dukor, Basel

L. Edebo, Göteborg

W.P. Faulk, Charleston, S.C.

P.G.H. Gell, Birmingham

H. Gewurz, Chicago, Ill.

I. Glazer, Tel Aviv

R.A. Good, New York, N.Y.

M. Hess, Bern

L. Hudson, Beckenham

H. Isliker, Lausanne

S.G.O. Johansson, Stockholm

E.A. Kabat, New York, N.Y.

K. Kano, Tokyo

W. Müller-Ruchholtz, Kiel

Ö. Ouchterlony, Göteborg

Z. Ovary, New York, N.Y.

P. Perlmann, Stockholm 


\author{
E. Pick, Tel Aviv \\ M. Plaut, Baltimore, Md. \\ R.E. Reisman, Buffalo, N.Y. \\ G. Riethmüller, München \\ M. Roitt, London \\ K. Rother, Heidelberg \\ G. Sandberg, Stockholm \\ H.D. Schlumberger, Wuppertal \\ A. Sehon, Winnipeg \\ E. Sorkin, Davos Platz \\ H. Storck, Zurich \\ A. Szentivanyi, Tampa, Fla. \\ T.B. Tomasi, Jr., Rochester, Minn. \\ O. Tönder, Bergen \\ G. Torrigiani, Geneve \\ J.L. Turk, London \\ E.R. Unanue, Boston, Mass. \\ B.H. Waksman, New York, N.Y. \\ A.L. de Week, Bern \\ G. Wick, Innsbruck \\ DBffl
}

Contents Vol. 70,1983

No. 1

Original Paper

Characaterization of a Factor from Rat Serum with Blocking

Activity in the Passive Cutaneous Anaphylactic Reaction

Theobald, K.; König, W

1

Complement Components, $\mathrm{Cl}$ Activation and Disease Activity

in SLE

Sturfelt, G.; Sjöholm, A.G.; Svensson, B 12

Effect of Metal Allergens on Thymocytes from Unsensitized

Guinea Pigs: A Comparative Light and Electron Micro

scopic Study

Nordlind, K.; Thy berg, J 19

Antibodies to Purified Protein Derivative in Different Immu-

noglobulin Classes in the Diagnosis of Tuberculosis in Man

Radin, R.C.; Zeiss, C.R.; Phair, J.P 25

Leukocytes from Patients Allergic to Chromium and Nickel

Examined by the Sealed Capillary Migration Technique

Nordlind, K.; Sandberg, G 30

Immunopotentiation of Cell-Mediated Hypersensitivity by Co-

rynebacteríum parvum (Pwpionibacterium acnes)

Maguire, H.C., Jr.; Cipriano, D

34

Expression of FcIgG Receptors on Cultured Fetal Rat Brain Cells. Studies on Normal, Preneoplastic and Malignant Cells Aanderud, S.; Lillehaug, J.; Tønder, O.; Laerum, O.D. ... 40 
Effects of Hydrocortisone and Protein Synthesis Inhibitors on

FcIgG Receptors on Cultured Fetal Rat Brain Cells

Aanderud, S.; Lillehaug, J.; Matre, R 46

Histopathology of Delayed-Onset Hypersensitivities in Con

tact-Sensitive Guinea Pigs

Godfrey, H.P.; Phillips, M.E.; Askenase, P.W 50

Production of Migration Inhibitory Factor by Lóm' $\alpha$-Immune

Mouse T Lymphocytes, but not B Lymphocytes

Kearns, R.J.; Campbell, P.A 59

Tuberculin Anergy in Clinically Normal Individuals. I. Lym-phokine and Lymphocyte

Transformation Studies Muller, H.K.; Pye, D.W.; Martin, C.L.; Kimpton, W.G. . 65

The Mechanism of Passive Sensitization: Occupation of Free

IgE Receptors or Exchange with Cell-Bound IgE

Van Toorenenbergen, A.W.; Aalberse, R.C.; Reerink-Bron-

gers, E.E $\quad 71$

Release of Eosinophil Chemotactic Leukotriene from Neutro-

phils of Patients with Pseudo-Allergic Reactions

Czarnetzki, B.M 78

The Release of Histamine from Rat Mast Cells by Chymotryp-

$\sin$

Nials, A.T.; Vardey, C.J.; Skidmore, I.F 83

Perfluorocarbon Enhancement of Heterologous Red Cell Survival: A Reticuloendothelial Block

Effect? Castro, O.; Reindorf, C.A.; Socha, W.W.; Rowe, A.W. ... 88

Short Communication

Effects of Fibrinogen Fragment and Proteolytic Enzyme on the Immune System in Mice

Ahlstedt, S.; Hessel, B.; Nilsson, B.S.; Sohl-Åkerlund, A.;

Wedel, I.; Widström, $0 \quad 92$

96

Book Reviews

No. 2

Original Paper

Decrease of E and EA but not EAC Rosette Formation after

Incubation of Blood Lymphocytes in Cerebrospinal Fluid

Næss, A 97

Lymphocyte Receptors for Human Erythrocytes in Newborn

Infants and Adults. Expression on Fresh and Lectin-Stimu-

lated Cells

Hallberg, A.; Hallberg, T 100

Determination of Antibodies to Partially Purified Aspergillus

Antigens by an Enzyme-Linked Immunosorbent Assay

Schønheyder, H.; Andersen, P

108

Kinetics and Drug Sensitivity of the Anti-Hapten and Anti-

Carrier IgG1 and IgG2 Antibody Production in Guinea

Pigs

Drossier, K.: Klima, F.; Ambrosius, H 112 
Production of Two Lymphocyte Chemotactic Factors by Anti gen-Stimulated Guinea Pig Lymphocytes

Harita, S.; Shimokawa, Y.: Hayashi, H 118

Antibodies against Polyethylene Glycol Produced in Animals

by Immunization with Monomethoxy Polyethylene Glycol

Modified Proteins

Richter, A.W.; Åkerblom, E 124

Detection and Characterization of Polymers in Cephalothin by

Passive Cutaneous Anaphylaxis in Mice

Iwata, M.; Tokiwa, H.; Matuhasi, T 132

Passive Anaphylaxis in Human Lung Fragments as a Model for

Testing Anti-Allergic Drugs: Its Variability and Con

straints

Young, K.D.; Church, M.K 138

Effect of BSA on Ca2+ Influx in Mast Cells Stimulated by Oval-

bumin

Tanizaki, Y.; Townley, R.G 143

Autoantibodies to Tamm-Horsfall Protein in Acute and Chronic Hepatitis Lindberg, J.; Fasth, A.;

Norkrans, G.; Nilsson, L.-A. . . 146

HLA-Related Lymphocyte Responsiveness in Psoriasis

Gross, W.L.; Vorwerk, I.; Westphal, E.; Christophers, E.;

Hahn,G.: Schlaak, M 151

Contents

III

Detection of Antibodies Interacting with Glycosaminoglycan

Polysulfate in Patients Treated with Heparin or Other Poly-

sulfated Glycosaminoglycans

Wolf, H.; Nowack, H.; Wick, G

Peroral Immunization of Healthy Adults with Live Escherichia

coli 04K12 Bacteria. Antibody Response as Measured in

Serum and Secretions

Kaijser, B 164

The Activity of a New, Novel Inhibitor of Leukotriene Synthesis in Rhesus Monkey Ascaris

Reactors Johnson, H.G; McNee, M.L.; Bach, M.K.; Smith, H.W . 169

Effect of Antihistamins (HI and H2), Cortisone and Beta-

Adrenergic Stimulator on Murine Contact Sensitivity and

Histamine Metabolism

Olafsson, J.H.; Granerus, G.; Roupe, G 174

Suppression of Contact Sensitivity by IgG 1 Antihapten Anti

body. IgG 1 Antihapten Antibody Suppresses Migration In

hibitory Factor Production by Lymph Node Cells

Katayama, I.; Nishioka, K 178

Antigen Presentation by Macrophages from Adult Thymec-

tomised Mice

Schon-Hegrad, M.A.; Holt, P.G 185 
Short Communication

Inhibition of Lymphoid Cell DNA Synthesis by Metal Aller

gens at Various Concentrations. Effect on Short-Time Cul

tured Nonadherent Cells Compared to Nonseparated Cells

Nordlind, K 191

Detection of IgE Antibodies in Onchocerciasis Using a Semi-Purified Fraction from

Dipetalonema viteae Total Antigen

Ouaissi, A.; Moutis, J. des; Cornette, J.; Pierce, R.; Capron, A. 231 Physicochemical Properties

and Blood Clearance of Human

Serum Albumin Conjugated to Different Extents with Di-

nitrophenyl Groups

Skogh, T.; Stendahl,O.; Sundqvist, T.; Edebo, L 238

Biosynthesis and Release of Platelet-Activating Factor from

Human Monocytes

Camussi, G.; Bussolino, F.; Tetta, C; Piacibello, W.; Agliet-

ta, M 245

Mechanism of BCG-Activated Macrophage-Induced Tumor

Cell Cytotoxicity: Evidence for Both Oxygen-Dependent

and Independent Mechanisms

DiStefano, J.F.; Beck, G.; Zucker, S 252

Adenylate Cyclase, Cyclic AMP and IgE-Mediated Desensitiza-

tion in Rat Mast Cells

Mendoza, G.R.; Orner, F.B 261

Formation of Biologically Inactive Polymers is Responsible for

the Thermal Inactivation of Rat IgE

Rousseaux-Prévost, R.; Rousseaux, J.; Bazin, H.; Biserte, G. 268 Granulocyte-Mediated Release of Histamine from Mast Cells.

Effect of Myeloperoxidase and Its Inhibition of Antiinflam-

matory Sulfone Compounds

Stendahl, O.; Molin, L.; Lindroth, M 277

Short Communication

Attempt to Infect the Nine-Banded Armadillo with Treponema

pallidum

Wicher, K.; Kalinka, C; Walsh, GP 285

News Item

288

No. 3

Original Paper

Storage and Turnover of Histamine, 5-Hydroxytryptamine and

Heparin in Rat Peritoneal Mast Cells in vivo

Wingren, U.; Wasteson, Å.; Enerbäck, L 193

Naturally Developing Antibodies to Wheat Gliadin Fractions

and to Other Cereal Antigens in Rabbits, Rats and Guinea

Pigs on Normal Laboratory Diets 
Coombs, R.R.A.; Kieffer, M.; Fraser, D.R.; Frazier, P.J. . 200 Cow's Milk Protein Intolerance in Children is Connected with

Impaired Lymphoblastic Responses to Mitogens. Preliminary Report

Fällström, S.-P.; Lindholm, L.; Ahlstedt, S 205

Factors in the Sera of Tumor-Bearing Mice Modifying the

Charge of Immune Cells

Vaillier, D.; Vaillier, J207

A Rapid Procedure for Crossed Radio Immunoelectrophoresis

Uhlin, T.; Einarsson, R

213

Increased 'T Lymphocyte' Bearing Fc Receptors for IgG in

Pregnancy

Ong, K.S.; Grieco, M.H.; Goel, Z 220

Changes of Alpha i-and Beta-Adrenergic and Cholinergic Mus-

carinic Receptors in Guinea Pig Lung Sensitized with Oval-

bumin

Mita, H.; Yui, Y,; Yasueda, H.; Shida, T 225

No. 4

Original Paper

Cyclosporin A: Alterations of the Cellular Immune Response in

S-Antigen-Induced Experimental Autoimmune Uveitis

Nussenblatt, R.B.; Salinas-Carmona, M.; Waksman, B.H.;

Gery, 1289

Antiallergic Activity of Nylidrin Hydrochloride (RHC 3432-

A). I. Effect on Release of Histamine in vitro from Rat

Peritoneal Mast Cells, Guinea Pig Lung Slices and Human

Basophils

Khandwala, A.; Coutts, S.; Weinryb, 1295

Antiallergic Activity of Nylidrin Hydrochloride (RHC 3432-

A). II. A Lack of Correlation between Inhibition of Media

tor Relase and Levels of Cyclic AMP

Coutts, S.M.; Khandwala, A.; Weinryb, 1303

RHC 3024: Antiallergic Activity in vitro and Comparison with

Disodium Cromoglycate and Other Antiallergic Agents

Khandwala, A.; Coutts, S.M.; Dally-Meade, V.; Jariwala,

N.; Huang, F.-C 311

IV

Contents

Regulation of Lymphocyte Transformation by Components Identified in Ultrafiltrates Prepared from Leukocyte Extracts

Sakatsuji, K..; Gottlieb, A.A.; Inui, J.; Ohno, T.; Nakamine,

H.; Nishimoto, Y.; Kawaguchi, Y.; Saito, K 321

On the Secretory Process of Rat Mast Cells and Rat Basophilic

Leukaemia Cells. Effects of Aggregated IgGa on 45Ca Influx

and Histamine Secretion

Möller, G.; König, W 331 
Conditions for the Enhancing Effect of Protease Inhibitiors on the Concanavalin A Induced Thymidine Response of Mu-rine Lymphocytes

Hammann, K.P.; Scheiner, O.; Raile, A.; Schulz, T.;

Schopf, R.E.; Peters, H.; Erdei, A.; Dierich, M.P 337

Distribution of IgM-, IgG-, and IgA-Positive Cells in Lym

phatic Organs of Normo- and Dysgammaglobulinemic

UM-B19 Chickens

Hoffmann-Fezer, G.; Lösch, U 346

Properties of Two Monoclonal Antibodies Directed against the

Fc and Fab' Regions of Rat IgE

Conrad, D.H.; Studer, E.; Gervasoni, J.; Mohanakumar, T. 352 A C5-Derived Macrophage

Chemotactic Factor from DNP-

Ascaris Extract-Induced Skin Lesion in Guinea Pigs

Hirashima, M.; Hirotsu, Y.; Yoshimura, T.; Hayashi, H. . 361 Enhancement of IgE Antibody

Production by Ovalbumin

Aerosol in Mice

Imai, T.; Shimizu, F.; Fujimaki, H.; Watanabe, N 368

Short Communications

Heparin and the Dextran Anaphylactoid Reaction in Rats

West, G.B 373

Characterization of Anti-Double-Stranded DNA Antibody-

Forming Cells in the NZB/W Mouse Spleen

Okudaira, H.; Terada, E.; Ghoda, A.; Ogita, T.; Miyamo

to, T.; Nomura, T 376

Author Index $\quad 379$

S. Karger $\cdot$ Medical and Scientific Publishers $\cdot$ Basel

München $\cdot$ Pans $\cdot$ London $\square$ New York $\cdot$ Tokyo $\cdot$ Sydney

Drug Dosage

The authors and the publisher have exerted every effort to ensure that drug selection and dosage set forth in this text are in accord with current recommendations and practice at the time of publication. However, in view of ongoing research, changes in government regulations, and the constant flow of information relating to drug therapy and drug reactions, the reader is urged to check the package insert for each drug for any change in indications and dosage and for added warnings and precautions. This is particularly important when the recommended agent is a new and/or infrequently employed drug.

All rights reserved.

No part of this publication may be translated into other languages, reproduced or utilized in any form or by any means, electronic or mechanical, including photocopying, recording, microcopying, or by any information storage and retrieval system, without permission in writing from the publisher or, in the case of photocopying, direct payment of a specified fee to the Copyright Clearance Center (see 'Information for Readers and Subscribers').

(C) Copyright 1982 by S. Karger AG, P.O. Box, CH-4009 Basel (Switzerland) Printed in Switzerland by Buchdruckerei Basler-Zeitung AG, Basel 